\title{
Survey of sandfly vectors of leishmaniasis in Marambaia Island, municipality of Mangaratiba, State of Rio de Janeiro, Brazil
}

\author{
Shênia Patrícia Corrêa Novo ${ }^{[1]}$, Marcos Barbosa de Souza ${ }^{[1]}$, Ciro Benigno Villanova ${ }^{1}$ \\ Jairo Caetano Meródio ${ }^{[1]}$ and Antônio de Medeiros Meira ${ }^{[1]}$
}

[1]. Departamento de Ciências Biológias, Escola Nacional de Saúde Pública Sérgio Arouca- Fundação Oswaldo Cruz, Rio de Janeiro, RJ.

\begin{abstract}
Introduction: The influx and efflux of military personnel in the possible endemic areas of leishmaniasis provided the impetus for research on the sandflies on Marambaia Island. Methods: Sandflies were collected with light traps installed in the 3 ecotypes of 3 areas chosen for their particular landscape aspects. Results: In 2009, were collected 32,006 specimens of sandflies belonging to 13 species. The species that showed highest density were Nyssomyia intermedia and Migoneimyia migonei. Conclusions: $N$. intermedia and M. migonei are the principal vectors of American tegumentary leishmaniasis (ATL) in Brazil; thus, extension studies related to the eco-epidemiology of these species of Marambaia Island are essential.
\end{abstract}

Keywords: Leishmaniasis. Sandfly fauna. Marambaia Island.

Several sandfly species have been reported to carry natural infections by Leishmania spp. In Brazil, American tegumentary leishmaniasis (ATL) deserves attention due to its considerable magnitude and high risk of deformities in humans ${ }^{1}$. In the State of Rio de Janeiro, several studies relating to ATL epidemiology have indicated Nyssomyia intermedia as the species with the highest vector potential to transmit ATL in domicile and peridomicile environments in the region, because of its density, anthropophily, and easy adaptation to anthropic environments ${ }^{2,3}$. More recently, Migoneimyia migonei has been documented as another species with high vector potential ${ }^{4}$. According to the Ministry of Health in $2007^{1}$, AVL (also known as kala-azar and barriga d'água) has been expanding to urban areas. Its main vectors in Brazil are the Lutzomyia longipalpis and Lutzomyia cruzi species, which has been found in natural infections in Corumbá and Jaciara in the State of Mato Grosso do Sul ${ }^{5,6}$.

The risk of parasite transmission depends on the existence of a large number of vector species in addition to the emergence of species that used to be restricted to the wild. The epidemiological importance of these insects is linked to species that are effectively associated with the anthropic environment.

An important factor in Marambaia Island is the influx and efflux of military personnel in the possible endemic areas of leishmaniasis.

The objective of the present study was to determine the number of sandfly species and identify the epidemiologically

Address to: Dra. Shênia Patrícia Corrêa Novo. Rua Leopoldo Bulhões 1480, Manguinhos, 21031-210 Rio de Janeiro, RJ, Brasil.

Phone: 5521 2598-2563

e-mail: shenia@ensp.fiocruz.br

Received 09 June 2011

Accepted 30 September 2011 important species for the transmission of leishmaniasis in the Center for Military Training in Marambaia Island (CADIM).

Marambaia Island $\left(23^{\circ} 04^{\prime} 51^{\prime \prime} \mathrm{S}-44^{\circ} 00^{\prime} 39^{\prime \prime} \mathrm{W} 23^{\circ} 03^{\prime} 48^{\prime \prime} \mathrm{S}\right.$ $\left.-43^{\circ} 33^{\prime} 96^{\prime \prime} \mathrm{W}\right)$ consists of an ecological reserve that has very distinct topography and vegetation, with a beach, restinga, hillside woods, and marsh areas ${ }^{7}$. This location is occupied by a quilombola community (remains of a quilombo, i.e., descendants of slaves). A survey carried out by the National Institute for Colonization and Agrarian Reform (INCRA) in 2006 estimated the existence of approximately 262 quilombola families in the region ${ }^{8}$. In addition, the island is visited annually by hundreds of thousands of people coming from different leishmaniasis-endemic regions in Brazil.

The present work was conducted in 3 distinct ecotopes (intradomicile, peridomicile, and woods) in 3 regions of Marambaia Island in the municipality of Mangaratiba: Pescaria Velha, Praia do Sítio, and Praia Grande. These regions were selected according to their landscape, vegetation, and anthropic activity characteristics.

The capture methodology included the use of the suction light trap (Centers for Disease Control [CDC] Model) ${ }^{9,10}$. Collection with light traps began at 6:00p.m. and ended at 7:00a.m. the next morning, totaling $13 \mathrm{~h}$ of collection per trap. The collected specimens were placed in plastic tubes containing $70 \%$ alcohol. They were duly labeled and sent to the laboratory, where they were prepared and placed between microscope slides and cover slips in Canada Balsam. The collected specimens were then identified according to Galati's taxonomic nomenclature, $2003^{11}$.

Throughout the 12 collection months in the study area, we performed monthly collections of sandflies using a CDCtype light trap. A total of 32,006 specimens from 13 species 
were captured: $N$. intermedia, Migoneimyia migonei, Pintomyia fischeri, Lutzomyia longipalpis, Evandromyia edwardsi, Pintomyia bianchigalatiae, Brumptomyia brumpti, Evandromyia cortellezii, Expapillata firmatoi, Micropygomyia capixaba, Micropygomyia quinquefer, Micropygomyia schreiberi, and Psathyromyia pelloni. The species N. intermedia and M. migonei were predominant, representing $80 \%$ and $18.7 \%$ of the captured sandflies, respectively (Table 1).

TABLE 1- Sandflies populations captured during 2009 in Marambaia Island, Rio de Janeiro, Brazil

\begin{tabular}{|c|c|c|c|c|c|c|}
\hline \multirow[b]{2}{*}{ Species } & \multicolumn{2}{|c|}{ Male } & \multicolumn{2}{|c|}{ Female } & \multicolumn{2}{|c|}{ Total } \\
\hline & $\mathrm{n}$ & $\%$ & $\mathrm{n}$ & $\overline{\%}$ & $\mathrm{n}$ & $\%$ \\
\hline Nyssomyia intermedia & 12,259 & 48.0 & 13,320 & 52.1 & 25,579 & 80.0 \\
\hline Migoneimyia migonei & 3,389 & 56.6 & 2,598 & 43.4 & 5,987 & 18.7 \\
\hline Pintomyia fischeri & 21 & 12.3 & 149 & 87.6 & 170 & 0.5 \\
\hline Lutzomyia longipalpis & 73 & 67.6 & 35 & 32.4 & 108 & 0.3 \\
\hline Evandromyia edwardsi & 13 & 21.0 & 49 & 79.3 & 62 & 0.2 \\
\hline Pintomyia bianchigalatiae & 4 & 11.0 & 33 & 89.2 & 37 & 0.1 \\
\hline Brumptomyia brumpti & 10 & 30.3 & 23 & 70.0 & 33 & 0.1 \\
\hline Evandromyia cortellezii & 0 & 0.0 & 2 & 100.0 & 2 & 0.006 \\
\hline Micropygomyia firmatoi & 0 & 0.0 & 1 & 100.0 & 1 & 0.003 \\
\hline Micropygomyia capixaba & 1 & 9.1 & 10 & 90.9 & 11 & 0.03 \\
\hline Micropygomyia quinquefer & 1 & 16.7 & 5 & 83.3 & 6 & 0.02 \\
\hline Micropygomyia schreiberi & 1 & 100.0 & 0 & 0.0 & 1 & 0.003 \\
\hline Psathyromyia pelloni & 9 & 100.0 & 0 & 0.0 & 9 & 0.03 \\
\hline Total & 15,781 & 49.3 & 16,225 & 50.7 & 32,006 & 100.0 \\
\hline
\end{tabular}

Among the species collected throughout 2009, 4 were of epidemiological importance to leishmaniasis transmission in Brazil: L. longipalpis, M. migonei, N. intermedia, and P. fischeri.

The CADIM is a location of national and international traffic of military personnel from several leishmaniasis-endemic regions. Additionally, the location is occupied by a community of quilombola descendants. These facts motivated our team to collect sandflies at this location and to conduct a survey of the sandfly fauna to detect leishmaniasis vectors, as the presence of humans possibly infected with the disease in contact with its vectors enables the presence, increase, or decrease of disease transmission dynamics. The study of sandfly ecology in Rio de Janeiro was initiated when tegumentary leishmaniasis (TL) cases occurred in the former capital of the Republic ${ }^{12}$. In the first studies of TL in Brazil, the presence of $N$. intermedia was already evident in modified environments. However, it was only after research conducted by Forattini and Santos ${ }^{13}$ that a high density of this vector was verified. Following this study, the hypothesis of its participation as the main transmitter of Leishmania braziliensis appeared ${ }^{14}$.

Pitta-Pereira et al. ${ }^{4}$ reported a natural infection in $N$. intermedia and M. migonei in studies of natural identification by L. (Viannia) braziliensis in specimens collected from different neighborhoods throughout Rio de Janeiro. These species are highly anthropophilic, and are potential ATL vectors in Brazil.

The main American visceral leishmaniasis (AVL) vector in Brazil, L. longipalpis, was appointed by epidemiological evidence as the vector of this protozoonosis in the municipality of Rio de Janeiro ${ }^{15}$ In the present study, L. longipalpis was captured in relatively low densities compared with species such as $N$. intermedia, an ATL vector. However, it is worth noting that since it was captured in the study locations and in greater density in the peridomiciles, in addition to the presence of seropositive dogs on Marambaia Island, there is a high possibility of the development of this disease.

The present study resulted in a great number of captured $N$. intermedia. This species was collected in all locations and all studied ecotopes, illustrating the high the level of importance of sandfly fauna studies on Marambaia Island. Since this species is of the greatest epidemiological importance for ATL in Brazil, it is vital to expand these studies related to eco-epidemiology on Marambaia Island. A similar result was observed for the M.migonei species, considered by many investigators as a secondary ATL vector in Brazil. The fact that there were 2 autochthonous ATL cases in the region, together with the finding of a great number of species that are vectors of this protozoonosis, adds to the importance of this study.

\section{CONFLICT OF INTEREST}

The authors declare that there is no conflict of interest.

\section{REFERENCES}

1. Ministério da Saúde. Secretaria de Vigilância em Saúde. Manual de vigilância e Controle da Leishmaniose Tegumentar America. Brasília: Ministério da Saúde; 2007.

2. Marzochi MCA, Marzochi KBF. Tegumentary and visceral leishmaniasis in Brazil - Emerging anthropozoonosis and possibilities for their control. Cad Saude Publica 1994; 10:359-375.

3. Souza MB, Marzochi MCA, Carvalho RW, Conceição NF, Ponte CS. Flebotomíneos em áreas de ocorrência de Leishmaniose Tegumentar no Município de São José do Vale do Rio Preto, Rio de Janeiro. Parasitol Al Dia 1995; 19:97-103.

4. Pitta-Pereira D, Alves CR, Souza MB, Brazil RP, Bertho AL, Figueiredo-Barbosa A. Identification of naturally infected Lutzomyia intermedia and Lutzomyia migonei with Leishmania (Viannia) braziliensis in Rio de Janeiro (Brasil) revealed by a PCR multiplex non-isotopic hybridization assay. Trans R Soc Trop Med Hyg 2005; 99: 905-913

5. Santos SO, Arias J, Ribeiro AA, Hoffman MP, Freitas RA, Malacco MAF. Incrimination of Lutzomyia cruzi as a vector of American visceral leishmaniasis. Med Vet Entomol 1998; 12:315-317.

6. Missawa NA, Veloso MAE, Maciel GBML, Michalsky EM, Dias ES. Evidência de transmissão de leishmaniose visceral por Lutzomyia cruzi no Município de Jaciara, Estado do Mato Grosso do Sul, Brasil. Rev Soc Bras Med Trop $2011 ; 44: 76-78$.

7. Conde MMS, Lima HRP, Peixoto AL. Aspectos florísticos e vegetacionais da Marambaia, Rio de Janeiro, Brasil. In: Universidade Federal Rural do Rio de Janeiro, editor. História Natural da Marambaia. Rio de Janeiro: Seropédica; 2005. p. 133-168.

8. Instituto Nacional de Colonização e Reforma Agrária [Internet]. [Cited 2009 April 30]. Available from: www.incra.gov.br/. 
9. Trpis MA. Sucction apparatus for collecting mosquitoes and other insects. Mosq News 1968; 28:647-648.

10. Sudia WD, Chamberlain RW. Battery operated light trap, an improved model. Mosq News 1962; 22:126-129.

11. Galati EAB. Classificação de Phlebotominae. In: Rangel EF, Lainson R, editors. Flebotomíneos do Brasil. Rio de Janeiro: Editora FIOCRUZ; 2003. p. 23-51.

12. Aragão HB. Transmissão da Leishmaniose no Brasil pelo Phlebotomus intermedius. Bras Med 1922; 36: 129.

13. Forattini OP, Santos MR. Nota sobre a infecção natural de Phlebotomus intermedius Lutz \& Neiva, 1912, por formas em leptomonas, em um foco de leihsmaniose tegumentar americana. Arq Hig São Paulo 1952; 17: 171-174.

14. Forattini OP, Oliveira O. Um foco de leishmaniose tegumentar na zona sul do Estado de São Paulo, Brasil. Arq Fac Hig Saude Publica Univ São Paulo $1957 ; 11: 23-24$.

15. Souza MB, Sabroza PC, Marzochi MCA, Coutinho SG, Souza WJS Leishmaniose visceral no Rio de Janeiro. I- Flebotomíneos de área de procedência de caso humano autóctone. Mem Inst Oswaldo Cruz 1981; 76:161-168. 